\title{
EDITORIAL
}

\section{THE REFORM OF THE EUROPEAN UNION: CHALLENGES AND OPPORTUNITIES}

Guest editors:

\author{
Valentin NAUMESCU, PhD Habil
}

Associate Professor, Faculty of European Studies, Babeş-Bolyai University, Romania valentin.naumescu@ubbcluj.ro

\section{Margriet KRIJTENBURG, PhD}

Senior Lecturer \& researcher, The Hague University of Applied Sciences, the Netherlands G.Krijtenburg@hhs.nl

Keywords: European Union, crisis, reform, challenges, opportunities.

It is almost a commonplace to reiterate today the formula of the "existential crisis" (Juncker, 2016) of the European Union, as the President of the European Commission named it in his 2016 State of the Union Address. Two years after the Brexit referendum, the way forward is still not clear neither for the UK nor for the EU27.

The European elections in May 2019 pose a threat for the Union and represent an unpredictable challenge for the pro-European parties. The quick decline of the President Macron's popular support to 28\% (Challenges, 2018) and the approaching of the end of the "Merkel era" give also motives of concern for the supporters of the European Union. The ascension of radical nationalist and Eurosceptic platforms in the West but also in Central Europe resuscitate old cleavages and fears on the European continent. Would it be therefore more or 
less Europe the solution for the future of the Union? To reconcile the two divisive options, President Juncker and the European Commission established in 2017 a task force under a slogan which would be in-between: "Doing less, more efficiently" (European Commission, 2017). But this new approach did not stir the enthusiasm neither in the pro-European camp nor in the Eurosceptic one.

Under these circumstances, the "Macron Plan" (Fondation Robert Schuman, 2017) for an "EU re-foundation" seems more than ambitious, but rather a political adventure on high seas. A new EU Treaty is however difficult to imagine nowadays. Not because it wouldn't be necessary after the UK leave, but because of the lack of political consensus in the EU27 and of the high risk that, even if the negotiations between the governments would be successful, a new Treaty would be rejected somewhere in a national referendum. So little political action is really possible today, in the current context.

It seems to be a contradiction between the voices asking for urgent, deep and structural reforms and those claiming a return of competencies and responsibilities from Brussels to national governments. The need of reforms is huge but the instruments and possibilities are very limited. As Stefan Lehne remarks for Carnegie Europe, "the European Union is stuck in no-man'sland-needing to reform to keep up with changing risks and voter sentiment, yet hardly able to do so because of internal divisions and lack of support from the European public. The negotiations on the next seven-year budget framework may help address some of the most pressing needs for adjustment. Because of their technical nature, however, these talks will do little to restore voter confidence in the EU, leaving a heightened risk of political disruption" (Lehne, 2018).

It is not only the extended European Union itself which is undergoing a long period of turbulence, but also its vicinities that were left out. The EU's Eastern Neighbourhood and the Western Balkans lost most of their pro-European enthusiasm in the past decade, while waiting at the EU's door. Today "Eastern Europe" is no longer the communist Europe, but the cleavages persist and the region is still not entirely included in the European Project, almost 30 years after the collapse of the communist regimes. The Eastern Partnership (EaP), the Association Agreements (AAs), the Deep and Comprehensive Free Trade Agreements (DCFTAs) and even the statute of candidate states for EU accession have not proved to be effective instruments and 
solutions for a complete and profound Europeanization of these countries, mainly because "the tragedy of Eastern Europe, in its old and new version, is [...] represented by the same paradoxical cleavage between its high geopolitical significance and the economic weakness of the region" (Naumescu, 2015: 19).

The recent research of the EU crisis has been usually focused on two main thematic dimensions. The first area of interest regards the political, economic and institutional capacity of the European Union to deal with the new problems and challenges, to propose new public policies and approaches in the context of a changing world, including the dynamics of the European societies. The second major subject is a cultural research of the European malaise, starting from a growing mistrust in the European Project and the decline of the liberal values and taking into consideration the revival of identity approaches, nationalism and new sensitivities of political culture on the continent, such as the need of protection, security, stability, religion or traditional values.

The current issue of the On-Line Modelling New Europe respects the multidisciplinary trends in European studies, debating the crisis of the European Project, but it also converges more on policy studies, solutions and perspectives. The research question that tries to unify all articles is whether the reform of the European Union in its various field is determined by values and principles and responds to theoretical and ideological models or is it driven by more pragmatism, a transactional view and a mix of interests?

"In our minds, European policy is in no way at odds with the patriotic ideal we all share [...] the nation has a role to play vis-à-vis its own citizens, but also, and just as much, vis-à-vis other nations. It cannot therefore retreat into the first of those roles." (Schuman, 2010, pp. 133-134) These words were spoken in 1961 by Robert Schuman, unanimously acclaimed 'Father of Europe' by the first European Assembly, the forerunner of today's European Parliament. Starting at the root of the European unification project to get a deep understanding of its objective, it is clarifying to know that Schuman and the other main Founding Fathers envisioned a European unification process that safeguarded regional and national identities to the extent that they did not go against the European common good. They held that the Greek-Roman traditions and the Jewish-Christian heritage were the common spiritual and cultural roots shared by western, 
eastern and central European countries and regarded this as the soul of the European unification project.

The focal point of the project was to be the person with his social and spiritual dimension and the economic cooperation that led to political integration was meant to serve the person's development. (Krijtenburg, 2012, pp. 66 - 76) The European spirit implied, using Schuman's words, "being conscious of belonging to a cultural family and wanting to serve that community in the spirit of total mutuality, without any hidden motives of hegemony or the selfish exploitation of others." (Schuman, 1949). Regarding the European project this meant that "This 'whole' cannot and must not remain an economic and technical enterprise: it needs a soul, the conscience of its historical affinities and of its responsibilities, in the present and in the future, and a political will at the service of the same human ideal" (Schuman, 2010, p. 58 ).

The European founders had in mind a unification process consistent with the moral order proceeding from natural law and thus also in accordance with the human psyche. The frame of reference for European integration consisted of: the search for reconciliation where needed; effective solidarity; subsidiarity; and the agreement on supra-nationality when this was required for the broader national, European and universal common good (Krijtenburg, 2012, pp. 66-76). As mentioned in the Schuman Declaration (1950) this would allow Europe to flourish and to foster the world's, especially Africa's, development as "[The solidarity of] production [would] be offered to the world as a whole without distinction or exception, with the aim of contributing to raising living standards and to promoting peaceful achievements. With increased resources Europe [would] be able to pursue the achievement of one of its essential tasks, namely, the development of the African continent."

It can be assumed that if this frame of reference had been put in practice, the majority of African migrants might not (have) come to Europe in search for a better future as they could have secured their livelihood in their own countries. The intriguing fact is that today's crisis in Europe can for a large part be regarded as a consequence of EU's deviation from its initial frame of reference. Economic and technological interests seem to have become the main drive and goal of the European unification project instead of providing the means to serve the person and his social and spiritual dimension. This has also fuelled the so-called "identity politics" of today as 
large and minority groups demand to be heard in politics. Political scientist and philosopher Francis Fukuyama suggests that "identity politics" often leads to polarization and is a threat to democracy, taking Brexit and the USA as clear examples (Fukuyama, 2018). Pope Francis stresses the need to continue to build bridges through dialogue between all groups. (Pope Francis, 2017)

The topicality of the original frame of reference for European unification turns out to be increasingly relevant in the search for universal guiding principles that foster interconnectedness and a focus on the common good. It is especially the younger generation that seeks a transformation of current structures into structures of solidarity.

An example is Volt (NRC, 2018), the first pan-European political movement with a presence in 32 European countries, that started as a reaction to Brexit and the rise of the divisive and destructive trend of populism. It is mainly led by people between 20 and 35 years old, but also attracts older and even younger people. The movement aims to start a new and inclusive way of doing politics, wanting to bring real change to all European citizens. Its vision is that of a new panEuropean approach which is needed to meet current and future challenges, such as climate change, economic inequality, migration, international conflict, terrorism, and the impact of the technological revolution on jobs. The members of Volt see national parties as powerless in the face of these challenges that go beyond national borders and need to be tackled by Europeans, as one people. In their General Assembly in Amsterdam on 27-28 October 2018, they mentioned that "As a transnational party, we believe we can help the European people unite, create a shared vision and understanding, exchange good practices across the continent, and come up with policies together." This way of reasoning is clearly in line with the original guiding principles for European integration. Their members focus on the acquisition of personal leadership virtues, knowing that leadership is character aimed at service in the interest of the greater good. They foster constructive dialogues with those that could be qualified as their opponents, they practice effective solidarity with people in need, and subsidiarity to elicit the strength in those that should be able to help themselves but need a slight push. They aim at the appropriate modification of laws, market regulations, and judicial systems and seem to agree with the observation of the Social Doctrine of the Church that " $a$ firm and persevering determination [is needed] to commit oneself to the common good. That is to say to the good of all and of each individual, because we 
are all really responsible for all. Solidarity is a fundamental social virtue since it places itself in the sphere of justice. [This means "serving" instead of "oppressing" for one's own advantage]" (Compendium Social Doctrine, 2004, Chapter 4). They acknowledge the strong bond between solidarity and the common good, solidarity and the universal destination of goods, solidarity and equality among men and peoples, solidarity and peace in the world. In this sense they seem to give heed to Schuman's observation that "What Europe wants is to uplift the rigidity of its borders. They should become the lines of contact where the material and cultural exchanges take place. They define the particular tasks, responsibilities and innovations proper to each country taking into account as well the problems all countries together - and even the continents - face and thus foster solidarity." (Schuman, 2010, pp. 26, 27) And equally they seem to underwrite Schuman's conviction that "It is in Europe's interest to remain the master of its fate. Splitting Europe up has become an absurd anachronism" and "We shall have to replace all the tendencies inherited from the past with the notion of solidarity, that is to say the conviction that the real interest of all lies in acknowledging and accepting the interdependency of all. Egoism does not pay any more." (Schuman, 2010, p.35)

No thorough judgement on Volt can be given as yet as it has only been in existence since 2017, but its intent seems to be a current expression of the original guiding principles of the European project. This movement may support reform that might contribute to Schuman's conviction that "This Europe which is still split up and torn, continues to be ever more aware of its calling to become the heart of a pacific cooperation of all peoples and of all races at the service of a humanity that embraces all continents." (Schuman, 2010, p. 30) The people of VOLT may correspond to Schuman's observation that "What Europe needs is a living faith, enthusiasm, abnegation and magnanimity. She will be created and her viability will need to be maintained by the young people and because of them, that is, with the active help of those that tomorrow will carry the heavy burden of assuring a future that is more or less threatened. We should not forget in this regard that it are the errors of the past generations that created this situation [...] but [...] it is absolutely necessary that the continuity and the cooperation of the best people of all sorts of ages and categories be assured." (Schuman, 2010, p. 58) 
One who looks for a unique answer or miraculous solution for this impasse will obviously fail. The local understandings, general perspectives, interpretations and possible solutions are different, taking into consideration various ideological, cultural, political and historic backgrounds on the continent: "there is no unique answer or panacea to this European malaise, the present crises or the structural threats haunting this changing, unpredictable world". (Naumescu, 2014: 13) Therefore we should expect a mix of interpretative theories and directions to go forward.

This collection of research article will show that the political, economic, social, cultural and spiritual dimension of the European integration project all shed a different light on the EU, and also that they are intrinsically connected and cannot be pulled apart. The following articles will provide evidence of their interconnectedness within and beyond the EU project of today and tomorrow.

\section{References}

1. CHALLENGES, (2018), "Macron perd 7 points de popularité à 28\%, son niveau le plus bas", 24 September 2018, Challenges, https://www.challenges.fr/politique/macron-perd-7-pointsde-popularite-a-28_614811, accessed in October 2018.

2. EUROPEAN COMMISSION, (2017), Future of Europe: President Juncker creates Task Force on 'doing less more efficiently', 14 November 2017, http://europa.eu/rapid/pressrelease_IP-17-4621_en.htm, consulted in October 2018.

3. FONDATION ROBERT SCHUMAN, (2017), "Emmanuel Macron's Europe. A vision, some proposals (policy paper)", European Issue, no. 445, October 2017.

4. FUKUYAMA, F. (2018), "Identity and global politics", Johns Hopkins University School of Advanced International Studies, 19 September 2018.

5. JUNCKER, J.-C. (2016), State of the Union Address 2016: Towards a Better Europe - a Europe that protects, empowers and defends, 14 September 2016, http://europa.eu/rapid/press-release_SPEECH-16-3043_en.htm, accessed in October 2018.

6. KRIJTENBURG, M. (2012), Schuman's Europe. His frame of reference, Leiden: Leiden University Press. 
7. LEHNE, S., (2018), "EU Reform: Does Everything Have to Change for Things to Remain the Same?", Carnegie Europe, July 19, 2018, https://carnegieeurope.eu/2018/07/19/eu-reformdoes-everything-have-to-change-for-things-to-remain-same-pub-76871, accessed in October 2018.

8. NAUMESCU, V. (2014), Democracy and Security in the $21^{\text {st }}$ Century: Perspectives on a Changing World, Newcastle upon Tyne: Cambridge Scholars Publishing.

9. NAUMESCU, V. (2015), "The New Eastern Europe and Cold War II" in Valentin Naumescu and Dan Dungaciu (editors), The European Union's Eastern Neighbourhood Today: Politics, Dynamics, Perspectives, Newcastle upon Tyne: Cambridge Scholars Publishing, 1-23.

10. POPE FRANCIS (2017) Address to the Commission of the Bishops' Conferences of the European Community, Rome, 28 October 2017.

11. RIJLAARSDAM, B. (2018), "De Europese partij Volt wil tegen de stroom in" ("The European Party Volt, wants to go against the grain"), Nieuwe Rotterdamse Courant (NRC), 29 October 2018.

12. SCHUMAN DECLARATION 1950.

13. SCHUMAN, R. Speech at the Council of Europe, Strasbourg, 16 May 1949.

14. SCHUMAN, R. (1955), "L'Europe est une communauté spirituelle et culturelle" In L'Annuaire Européen I, Scy-Chazelles: Archives Maison de Robert Schuman.

15. SCHUMAN, R. (2010) Pour l'unité de l'Europe. In: Du Pater Europae aux Pères de l'Europe, Milan: Silvana Editoriale.

16. SCHUMAN, R. (2010) For Europe, Geneva: Les Éditions Nagel.

17. SOCIAL DOCTRINE OF THE CHURCH, COMPENDIUM (2004), chapter IV.

18. VOLT, (2018) brochure General Assembly, Amsterdam. 27-28 October 2018. 